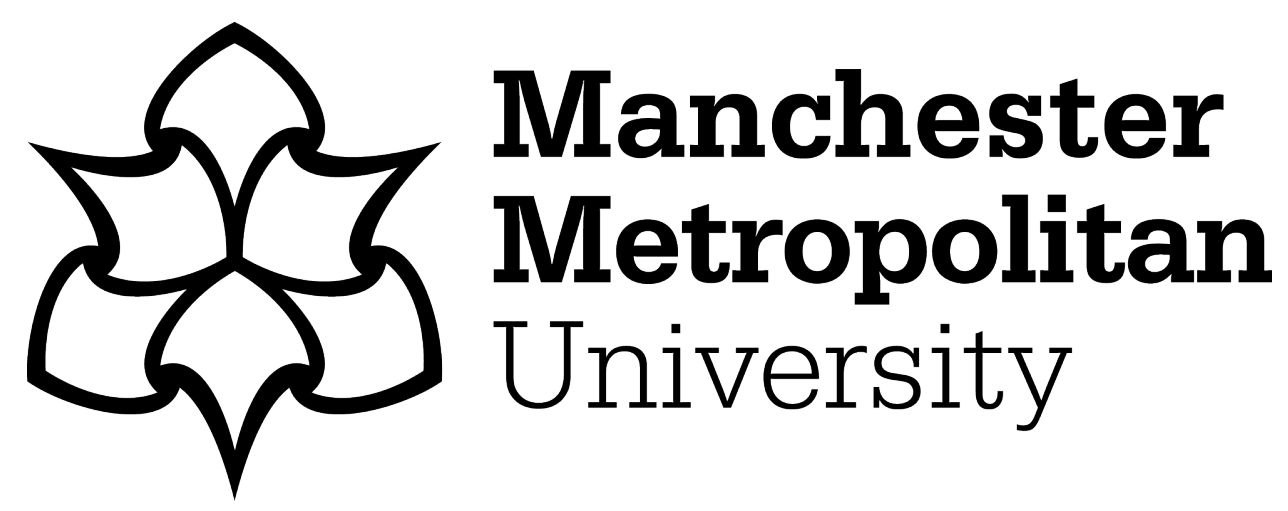

Sellar, S ORCID logoORCID: https://orcid.org/0000-0002-2840-5021 and Cole, DR (2017) Accelerationism: a timely provocation for the critical sociology of education. British Journal of Sociology of Education, 38 (1). pp. 38-48. ISSN 0142-5692

Downloaded from: https://e-space.mmu.ac.uk/623373/

Version: Accepted Version

Publisher: Taylor \& Francis

DOI: https://doi.org/10.1080/01425692.2016.1256190

Please cite the published version 


\title{
Accelerationism: A timely provocation for the critical sociology of education
}

Sam Sellar, Manchester Metropolitan University, s.sellar@mmu.ac.uk

David Cole, University of Western Sydney

\begin{abstract}
Accelerationism is a theoretical movement that seeks to mobilise reason and technological development as a strategy for moving beyond capitalism. The first wave of accelerationism took the effects of capitalism at their most pernicious and suggested that they have not gone far enough. More recent work has complicated this project and explored political, epistemic and aesthetic accelerations. The central push to accelerate, and therefore to manifestly alter time, has consequences in terms of how one understands temporality in education. The paper outlines the development of accelerationism and examines whether this theoretical movement can aid critical analysis of the growing presence of commercial technology providers, new modes of data analytics, and the application of machine learning algorithms to analyse education data. These developments provide a useful example in relation to which a critical question can be asked: Is it possible to accelerate technological development in education separate from its capitalist development?
\end{abstract}

\section{Introduction}

In the closing pages of his cartography of critical theory, Keucheyan (2013) proposes that '[ $t$ ]he task of critical thought ... is to make a new sense of temporality emerge' (p. 248). This proposal is framed by a discussion of Frederic Jameson's analysis of postmodernism, and follows a passing reference to Jameson's point that we now find it 'easier to imagine the end of the world than to imagine the end of capitalism' (2003, p.76). In recent years, there has been a surfeit of cultural production that supports Jameson's diagnosis of the temporal order, from visions of post-apocalyptic humanity in Cormac McCarthy's The Road, to post-human visions of artificial intelligence in Alex Garland's film Ex Machina. Mark Fisher's (2009) analysis of capitalist realism asserts that the foreclosed future that has been thrust upon us 'now' is played out in the educative ennui of reproduced classrooms teaching the facts of capitalism in a form of inescapable conformism. In contrast, Fisher (2013) situates 'accelerationism not as some heretical form of Marxism, but as an attempt to converge with, intensify, and politicize the most challenging and exploratory dimensions of popular culture' (p. 3).

Critical theory now faces the task of conceiving of a future that lies beyond the situation that Touraine (2001) describes as la pensée unique, that is to say, a capitalist normality, an endless now, or collapse of the temporal mode, which denies 'the existence of autonomous social actors capable of influencing political decision-making' (p.1). Beginning from the challenge to produce a new temporal order, this paper analyses accelerationism, understood as multifaceted theoretical movement concerned with relations between capital, technology 
and time. Accelerationism can be viewed as a provocation to the critical sociology of education, which must confront the risk that '[in] the absence of a new sense of temporality, no social change is conceivable' (Keucheyan 2013, p. 248). The provocation of accelerationism is important because when critical social theory does not aim, or cannot hope, to produce social change, it risks incoherence, irrelevance and obsolescence (Boltanski, 2011).

Accelerationism has gained traction as a means to understand and engage with the influences of capitalism and technology on everyday life. The basic premise of accelerationism is that capitalism has created, is creating, and will increasingly create, time-based, cybernetic feedback loops, in which time spirals in on itself as capital is continually reinvested in technological development. Acceleration, for one of its key theorists, Nick Land (2014a, p. 511), 'is techonomic time': a time in which, 'as basic co-components of capital, technology and economics have only a limited, formal distinctiveness under historical conditions of ignited capital escalation'. The potential divisibility of technology and capital is a key question for this paper and the relevance of accelerationism for critical sociology of education will be argued to depend on whether technological development in education can be accelerated separately from commercialisation.

Acceleration as techonomic time is illustrated in the work of analysts exploring the impact of machines on education and labour. For example, Brynjolfsson and McAfee (2014) show that, when plotted in relation to social development and global population, the course of human history explodes exponentially from the late 1700s, when the Industrial Revolution, and specifically the steam engine, 'ushered in humanity's first machine age - the first time our progress was driven primarily by technological innovation - and it was the most profound time of transformation our world has ever seen' (p. 9). Brynjolfsson and McAfee argue that we are now entering a second machine age during which exponential growth in computing power will change human history just as dramatically through a new phase of accelerated financial capitalism. Accelerationism takes this change as a primary theoretical focus and, needless to say, it is a change with wide-reaching consequences and challenges for education, including the growth of the education technology industry, new applications for machine learning in policy making and pedagogy, and dramatic changes to labour markets with effects on the demand for and value of educational credentials.

The promises of the knowledge economy, which often involve claims about the progress enabled by new computational technologies and the social mobility facilitated by lifelong learning, can readily become 'traps', characterised by intensified credential inflation as the many compete for the few lucrative jobs that have not been made redundant by digital Taylorism or low cost, high quality production (Brown 2006; Brown, Lauder and Ashton, 2010). Indeed, this 'opportunity trap' can be understood as one educational symptom of acceleration or technonomic time: a promise of progress that fuels intensifying (re)investments in the self. However, such investments appear unlikely to stave of the technological displacement of the middle class. Collins (2013, p. 68) argues that this displacement will precipitate 'the downfall of capitalism ... before the $21^{\text {st }}$ century is over'. While accelerationists generally do not subscribe to the view that capitalism will disintegrate 
under the weight of its own contradictions (Wolfendale 2014), accelerationists do see technological development as a force that can help to precipitate a post-capitalist future in conjunction with new social movements.

Acceleration can be juxtaposed with other contemporary theoretical movements that advocate slowing down time or passively waiting for an end to capital. For example, Berlant's (2011; 2016) writing about experimentally living on through the infrastructural glitches of capitalist breakdown represents a particularly powerful example of waiting with intent for a postcapitalist future. Berlant argues that 'at some crisis times like this one, politics is defined by a collectively held sense that a glitch has appeared in the reproduction of life' and 'the question of politics becomes identical with the reinvention of infrastructures for managing the unevenness, ambivalence, violence, and ordinary contingency of contemporary existence' (pp. 393-394). While Berlant points to the need for infrastructural reinvention, many contemporary political movements - for example, prominent strands of environmental politics - involve 'a romantic turn away from the modern, from technology' (Wark 2015, p. xv). Williams and Srnicek (2013) characterise such responses in terms of a 'folk politics of localism, direct action and relentless horizontalism' and argue for an alternative politics of acceleration which would be 'at ease with a modernity of abstraction, complexity, globality, and technology' (p. 354).

Left accelerationism offers possibilities for a politics that 'seeks to preserve the gains of late capitalism while going further than its value system, governance structures, and mass pathologies will allow' (Williams \& Srnicek, 2013). The work of theorists such as Berardi and Wark, who have engaged critically with the accelerationist provocation, offer interesting possibilities in this respect, because experimentation with accelerationist thought in educational research and practice would seek to understand the ways in which the harsh and exploitative aspects of capitalist intervention have simultaneously enabled transformative aspects of society and self that might help us exceed the constraints of the current situation (Cole, 2014). The key problem for education is to make the notion of accelerationism relevant and specific enough to be taken up in a field that is often unwittingly dominated by the normative beliefs of capitalism; i.e. that the exploitation of global markets through electronic mediation is necessarily 'good' and we 'should' all therefore become creative and innovative digital entrepreneurs.

Our focus in this article will be on acceleration as a theoretical resource that can provoke a new sense of temporality for the critical sociology of education and a new sense of critical agency in the accelerated temporal order. As a sociological concept, accelerationism augments understanding of how time is manipulated by the educational machinery around us, including the increasingly pervasive introduction and use of digital technology and the concomitant spread of commercialisation in education. If one accepts the basic premise of accelerationism, then the primary question for critical sociology of education is: Can technological acceleration be separated from capitalist acceleration? In this paper, we discuss an example of acceleration in education - the conjunction of commercialisation, new modes of data analytics and machine learning in education - and consider whether accelerationism can provide critical sociology of education with theoretical tools for thinking beyond the 
horizon of technologically-driven commercialisation of education and opportunity traps created by credential inflation and changing modes of production. The paper thus interrogates the related social, political and educational consequences of acceleration, beginning with a survey of the emergence of accelerationism as a theoretical movement across three 'waves' since the 1970s.

\section{The libertarian Post-Marxism of the 1970s}

Noys (2014) coined the term accelerationism to describe the the publication of three texts in the mid-1970s: Deleuze and Guattari's Anti-Oedipus (1972), Lyotard's Libidinal Economy (1974) and Baudrillard's Symbolic Exchange and Death (1976). While a longer history can perhaps be traced back to Samuel Butler's article, Darwin among the machines, which was published in 1863 and predicted a form of mechanical evolution, it is a short fragment from Deleuze and Guattari's Anti-Oedipus that constituted a decisive event in the development of accelerationist thought. The fragment proposes a heretical 'schizoanalytical' response to the spread of market capitalism:

But which is the revolutionary path? Is there one?-To withdraw from the world market as Samir Amin advises Third World countries to do, in a curious revival of the fascist "economic solution"? Or might it be to go in the opposite direction? To go still further, that is, in the movement of the market, of decoding and deterritorialization? For perhaps the flows are not yet deterritorialized enough, not decoded enough, from the viewpoint of a theory and practice of a highly schizophrenic character. Not to withdraw from the process, but to go further, to "accelerate the process"” as Nietzsche put it: in this matter, the truth is that we haven't seen anything yet. (Deleuze \& Guattari, 1983, pp. 239-240)

Deleuze and Guattari (1983) raise the possibility that capital's tendency to decode and deterritorialize might be seen as an ally in the project of remaking society. Revolution, in this case, would be a matter of conductance rather than resistance: deterritorialising the flows and accelerating the process. But what is to be accelerated here? This has become a central issue in accelerationist debates, and is also central for assessing whether accelerationism can usefully inform critical sociology of education.

One interpretation of how we might 'accelerate the process' comes from Davoli and Rustechelli (2014), who have argued that Deleuze and Guattari's reference to Nietzsche can be traced back to a fragment in The Will to Power notebooks. Here, Nietzsche (1968) writes that "Until now, 'education' has had in view the needs of society: not the possible needs of the future, but the needs of the society today' (p. 477). Deleuze and Guattari propose acceleration as an affirmation of the deterritorializing forces of capitalism, referencing Nietzsche's concern with hastening the processes of industrialisation and the freeing of forces that can be put to creative work in the overcoming of the human. Education is viewed as a significant node of resistance in this process, due to its focus on meeting present needs, rather than being mobilised to create new forces, subjects and social formations. Thus, Nietzsche 
posits a negative relationship between education and acceleration, which is reinforced by his comments on 'European man':

The homogenization of European man is the great process that cannot be obstructed: one should even accelerate it. The necessity to create a gulf, a distance, an order of rank, is given by itself: not the necessity to retard this process. (Nietzsche, 1877)

Such processes of inhuman homogenization were analysed as the emergence of 'onedimensional man' by the Frankfurt School. After World War Two, the 'European man' was rebranded and repackaged by North-American consumerist society, and today it exists in the new labour conditions of global logistics championed by 'NeoChina' (Pasquinelli, 2014, online). The homogenization is a consequence of global capitalism, which produces the dual effects of acceleration and deterritorialization on a planetary and unprecedented scale. The question for critical sociology of education, particularly in relation to its concern to interrupt social reproduction, is whether these tendencies can be affirmed as part of a broader transition that should and indeed only be hastened and which cannot be effectively resisted.

\section{The science fiction accelerationism of the 1990s}

During the 1990s, at the University of Warwick, a university lecturer stood out based on his reaction against the safety of the bureaucratically defined, over-determined, scholarly enclosure and his idiosyncratic approach to defying neoliberal conformism. Nick Land's lectures were 'events', and the series of conferences organised with him somewhere at the helm, called, 'Virtual Futures', temporarily transformed the uniformly dull slumber of university life. Revival in accelerationism and the resulting debates has come about due to the resurgence in interest in Land's thought, which has been reanimated as a pivotal accelerationist resource. It is worth examining Land's ideas from the 1990s, given that the third wave of accelerationism as we understand it now would be unrecognisable without his intervention (Land, 2011).

Land thought and wrote in the continental philosophical tradition and even though his work is not a conventional addition to this tradition, he takes up and grapples with its key philosophical questions. Land's ideas have their origins in the texts of Kant, Schopenhauer, Nietzsche, Heidegger, Bataille, Deleuze and others. Land's intention was to take the philosophical aspects of continental texts to their logical and illogical ends, particularly with respect to the temporal dimension. Land's accelerationism was based on philosophical understandings of time to be found in Nietzsche's eternal return, Deleuze's third synthesis in Difference and Repetition and in Heidegger's temporality of Dasein, yet he continuously questioned any unifying agency, I, or undivided human subjectivity behind these complex and enfolded-enfolding time dimensions.

Land was hostile to straightforward criticisms of capitalism and the reductive and simplifying ways in which capitalism is often caricatured by earnest leftists. In contrast, Land studied and used, for example, Marx's Capital and Grundrisse in his writings, as exemplary analyses of how capital works, but he was at the same time dismissive of Marxists, due to the purported 
inaccuracy of their material theses, sometimes overt ressentiment, and the parodies of capital and capitalism that could be produced. Land sought to understand how capitalism works on many levels at the same time (including the time dimension) and he denied that low level critical or rational analysis of capitalism from one limited perspective has any effect on its mode of functioning (for example, the condemnation of 'neoliberalism' that has become an ineffectual default strategy in much critical educational thought today).

Concurrent and convergent with a resistance to soft left criticisms of capitalism, Land produced (and still produces) a 'theory-fiction' synthesis of thought that aims to penetrate at a deeper level into the workings of capitalism than straightforward critical analysis. The inclusion of non-rational elements into Land's synthesis is reminiscent of the numerous theorists, scientists and artists who have previously explored the complex and recursive zone of contact between man and machine (e.g. Mumford, 1934), with the proviso that

techno-capitalist acceleration [à la Land] is not simply a process that will restore corrupted human relations under current technological infrastructures, but rather [it is] an inhuman desubjectification program that will renegotiate our basic notions of what it means to be human. Thus, what one may extract from [Land's] position is that the alienation we sometimes feel when encountering novel technological objects is not something that should be dismissed as threatening to our authentic selfhood, but a decisive vector of discovery that needs to be followed through rather than abolished. (Lindblom, 2012, online)

Land's accelerationism potentially reaches an immanent point at which prefigurative transformation and discovery about the future can occur, in contrast to, for example, any social or cultural revolution that merely stirs up present conditions before resetting them on a recalibrated footing. What exactly this action will lead to is not clear in Land's work, even though he is still giving clues to what he thinks could happen.

As [capitalist] culture folds back upon itself, it proliferates self-referential models of a cybernetic type, attentive to feedback-sensitive self-stimulating or autocatalytic systems. The greater the progressive impetus, the more insistently cyclicity returns. To accelerate beyond light-speed is to reverse the direction of time. Eventually, in science fiction, modernity completes its process of theological revisionism, by rediscovering eschatological culmination in the timeloop. (Land, 2014b, p. 376)

Land points to a 'science fiction' of the real as defining the enveloping reality of contemporary global capitalism. He does not look back with nostalgia at communism, nor at any mode of collectivism, as somehow saving us from the ravages of capital exploitation and division. Rather, he points to the darker sides of the techno-enabled processes within capitalism and, vis-à-vis education, sees capitalism as providing circuits and directions towards modes of thinking that go beyond the current situation (Cole \& Hager, 2010). 
In many ways, Landian accelerationism very precisely works as a heretical, oppositional, complexifying, and vertigo inducing force in contemporary critical theory. As Mackay has put it,

[Land's] heresy was twofold: it consisted not only in his attempt to 'melt' writing immanently into the processes it described, but also in his dedication to thinking the real process of Capital's insidious takeover of the human (and the legacy of this process within philosophy) - and in admitting the laughable impotence of 'man' in the face of this process. (Mackay, 2013, online)

While undoubtedly controversial, especially with respect to his right political tendencies, Land's work has profoundly shaped accelerationist thought and can potentially act as an irritant to the complacent theoretical and political progressivism that often underpins educational thought. For example, the positions of many contemporary opponents to standardised testing are underpinned by a romantic turn away from scientific measurement rather than working to outline more sophisticated approaches to assessment for learning that make use of growing technical capacities. Further, Land's concept of techonomic time provides an apt description of the potential for machines to displace the middle class and thus provides a useful reference point for theorizing this process and potential responses to the technological reworking of labour and education.

\section{The Promethean left accelerationism of the 2010s}

Recent interest in accelerationism constitutes a 'third wave' that has sought to legitimise acceleration as a leftist political strategy. There has been a move away from the heretical excesses of libidinal materialism and Land's anti-human embrace of the transformative forces of capitalism. While first and second wave accelerationism were somewhat hostile to conventional reproduction of Marxist thought, third wave accelerationism has looked to Marx's Prometheanism in order to pursue a rapprochement with the political agendas that Land criticised (see Mackay \& Avanessian, 2014). Thus, third wave acclerationism leaves open the ground for a political agenda around the issues that accelerationism addresses through a reconsideration of, for example, material dialectics in the light of an accelerated temporal milieu.

Two key developments in accelerationism, are particularly significant for our argument here. First, a distinction is now being drawn between Land's absolute acceleration, which eschewed politics, and a relative acceleration that can be mobilised as part of broader political strategy. As Williams (2013, p. 2) argues, "Land favoured an absolute process of acceleration and deterritorialization, identifying capitalism as the ultimate agent of history". There is little to be done politically from this perspective, beyond allying oneself with this deterritorializing process. Absolute acceleration forgoes the potential or desire to orient thought and action according to a set of political coordinates. In contrast, for relative acceleration, deterritorialization is employed as a tactic within a broader politics. Relative acceleration is thus more conducive to potential cross-fertilisation with research in the social sciences and education than Landian acceleration, due to its retention of a strategic focus on 
remaking society by breaking down current institutions and in celebrating the impulse to explore and develop the potentialities of rational thought and technological development.

Second, the answer to the question of what ought to be accelerated that has been given by some strands of accelerationism is rationalist modernity and technological development, as distinct from capitalism. A strategic accelerationism focused on the rationalist transformation of self and world that improve collective life could inform critical sociological analyses of educational practice. This variant of accelerationism is represented, for example, by the writings of Brassier (2014), Negarestani (2014) and Wolfendale (2016). As Mackay and Avanessian (2014) explain, for Negarestani "[a]cceleration takes place when and in so far as the human repeatedly affirms its commitment to being impersonally piloted, not by capital, but by a [rational] program which demands that it cede control to collective revision, and which draws it towards an inhuman future that will prove to have 'always' been the meaning of the human" (p. 31).

Here we see a subtle shift in exactly what might be accelerated, away from the time of capital, to the epistemic project of thinking beyond the human, a shift that echoes Nietzsche's call for the orientation of thought toward the future. Brassier argues that "Prometheanism is simply the claim that there is no reason to assume a predetermined limit to what we can achieve or to the ways in which we can transform ourselves and our world" (p. 471). This brand of accelerationism perhaps has the most to offer critical educational thought and practice, insofar as it focuses primarily on accelerating normative rationalism as a basis for revising and transforming the human. On this view, commitment to rational programs provides an alternative to the seduction of desires produced by capital. The role of education in this work would be to develop advanced critical thinking capacities among students and to incorporate into curricula the latest knowledge from fields such as cognitive science, computer science, genetics and STEM subjects more broadly. Here the term 'critical' would gain an additional sense, beyond the emphasis on uncovering systematic social domination that characterises its usage in sociology (Boltanski 2011), to also emphasise the 'critical' tipping points at which systems can be transformed and the work required to hasten sociotechnical progress, or deterritorialize, towards such points.

One area in which the enhancement of cognitive potentials to govern, teach and learn are being actively explored in education is through the development of new modes of data analysis that are operating in increasingly tight feedback loops with policy making, pedagogical decisions and student learning. One common response to such developments in critical education studies is suspicion, followed by a theoretical reflex response of deconstructing how relations of power are reworked by new technologies. While important, such approaches tend to leave unexplored other possibilities for actively engaging with new technological capacities as potential tools for remaking educational institutions and practices. To understand the impacts of acceleration on education and to demonstrate some possibilities for acceleration as a theoretical framework, we now turn to the example of data-driven educational governance and consider how the accelerationist provocation could encourage critical sociology of education to ask pivotal questions of these developments. 


\section{Acceleration in education: The example of new data analytics in educational governance}

In keeping with the theory-fiction genre of much accelerationist writing, we will discuss an example here that is grounded in current empirical circumstances while also speculating about the near future (see Blanchot 2006). ${ }^{i}$ Following Massumi (2002), we understand this as an 'exemplary methodology' that employs detailed examples to test out concepts - in this case, testing concepts drawn from accelerationism in relation to contemporary developments in educational governance. As large-scale quantitative data analyses gain influence in various sites of research and social policy production, critical sociology must become more adept at engaging with the frontiers of computational and information sciences or risk becoming redundant (Savage and Burrows 2007). The example we consider here will enable us to consider (a) how developments in information sciences put pressure on the theoretical resources of critical sociology and (b) whether tools from accelerationism may usefully augment these resources.

Since the 1950s, education systems, like many fields, have been rapidly developing new infrastructures for managing and analysing data (Sellar 2015). The data upon which education systems now run are combined from many sources, including demographic data collected by governments, administrative data relating to student behaviours such as attendance, and assessment data generated across multiple scales, from the local to the international. With the emergence of new modes of data analytics that enable the identification of correlations within very large data sets (Kitchin 2014), some education systems are now developing capacities for managing and analysing their increasingly large and complex data sets to better inform policy and pedagogical decisions. Here we will discuss the case of one Australian state education system - referred to here as System Athat is strategically implementing new and increasingly powerful modes of data analytics.

In many cases, the computational capacities required for powerful new modes of data analytics are, and indeed can only be, provided by large commercial organisations such as Microsoft, which is a major provider of business intelligence platforms. As a result, the education technology market has grown substantially in recent years, with substantial growth occurring particularly in the field of data analytics (Richards \& Stebbins 2014). System A now houses their data in large commercially-provided server farms and uses virtual machines to conduct bespoke queries of large data sets in very short time frames. The results of these analyses can be visualised in ways that ease human comprehension and enable action by policy makers or educators in schools. Machine learning algorithms have also been introduced to conduct these data analytics, reflecting growing interest in the economic and educational potentials of artificial intelligence in education (e.g. Luckin, Holmes, Griffiths \& Forcier 2016). Machine learning algorithms employ neural networks that 'learn' by checking probabilistic guesses against correct answers over multiple iterations to develop and refine abilities such as identifying text, speech or visual images.

We are now reaching the point in history where algorithms running on virtual machines in remote servers are becoming part of feedback loops between data analysis and decision making in sites such as System A. Here, analysis of population trends is being undertaken to 
modulate system-level schooling infrastructure, optimising provision geographically by identifying where to demolish schools and where to build new ones. Further, educators can use mobile devices to run data queries that inform their pedagogical decision making in very short time frames. The aim in this system is to reach a point of 'optimisation' where increasingly tight feedback loops between data analysis, professional development and pedagogical decision making contribute to improved learning. It is thus not far-fetched to claim that AI is already playing a role in this system and the aim is to steadily increase its agency.

Two key points are important here. First, the technological capacities that are enabling these developments are generally provided by commercial organisations. Second, the profits of these organisations - education is widely predicted to be the most profitable industry of the $21^{\text {st }}$ century - are being re-invested in further technological development. Education now operates within technonomic time as capitalist profit and technical development are locked into ever tighter feedback loops. The questions that left accelerationist position would ask of these circumstances are: Do these technological developments offer the potential to enhance human learning and rationality? Are these developments separable from the growth and involvement of commercial organisations that currently dominate provision? And, what infrastructures would need to be developed in order to effect such a separation and the independent development of educational technologies?

These are not questions that can be answered here in relation to the example of System A, but rather constitute a starting point for a research program in critical sociology of education that is informed by left accelerationism. For critical sociology to begin from these questions would constitute an important departure from the prevailing theoretical tendencies in the field, which begin from the questions about who wins and who loses from such developments and thus risk conflating the power inequalities generated by contemporary capitalism with the potentials that inhere in capitalist technological development (e.g. the capacity for machine learning to accelerate learning in some areas). Suspicion towards data-driven technologies as tools of governance and control is a default position some critical sociological analyses in education. Moreover, education, at all levels, and from every perspective, is readily caught in the divisions between what Williams and Srnicek (2013) call 'folk politics' and accelerationist alternatives. Most educationalists would feel somewhat ill at ease with the characterisation of being involved with a 'folk politics of localism', yet would also probably not want to be classed as accelerationists in the sense that Means (2015) understands this movement:

... accelerationists, like techno-utopians, believe that [socio-planetary] problems can simply be resolved through accelerating technological fixes such as through the mobilization of digitally networked "smart systems" and geoengineering projects (for instance blasting sulfur into the air in order to cool the planet's surface temperature to stave off climate change). However, technoscience cannot solve problems that are profoundly social and political in their constitution. (p.24) 
Naïve affirmation of techno-utopian developments is problematic. For example, Beradi (2014) takes a country like South Korea as an example of where the mantra and the possibly delusionary aspects of techno-capitalism have been fully embraced, and which, coincidentally, has the highest suicide rate in the world (p. 15). According to Beradi (2014), South Korean youth and the general public, who have been subjected to non-traditional, digitally mediated approaches to education for many years, are "constantly gazing at the screens of their smartphones, apparently driven by telepathic transmental signals ... [with a] lack of attention to the physical landscape surrounding them" (p. 15). Beradi (2014) is not making a necessary link between the augmentation of high-tech educational provision and problems with wellbeing or mental health, but he does raise the spectre of a whole series of subjective consequences of the potential technological overload, entrapment and conditioning.

Critics such as Beradi (2014) suggest caution and the need for in-depth critical analysis of the techno-capitalist power complexes that lie behind such innovations. Beradi (2014) links the accelerating subjective time dimension to global financial capitalist exploitation, and the ways in which agency may be conditioned and controlled through time, for example, by debt, credit, the market and finance structures. We suggest that such critical analysis of the changing time dimension of educational practice is necessary. However, it is possibile to combine critical-deconstructive analysis with approaches borrowed from Promethean relative accelerationisms, which are being actively developed by socio-political movements such as Xenofeminism that advocates a rational, technological and scientific response to injustices and negative transformations of the human; e.g. immaterial labour. We argue that developments such as data driven educational AI could also be engaged from an accelerationist perspective as holding potentials for informing rationalist educational programs that could improve learning outcomes and reduce inequalities and social domination.

\section{Discussion and conclusion}

Accelerationism is an emergent, fluid and diverse intellectual project and its political possibilities are still being explored. Concrete links to the sociology of education and the temporal dimension in educational practice are therefore currently unformed and open for debate. However, we have argued that the value of accelerationism lies in its capacity to provoke and irritate a comfortable, critical-progressive sense of temporality, acting as an antidote to becoming complacent or exhausted in the face of our 'capitalist realist' present. Accelerationism thus offers possibilities for the renewal of critical social theory and the analysis of the temporal dimension in education. The theoretical contributions that left accelerationism could make to critical sociology hinge on two key points: (1) the possibility of severing the acceleration of modernity and technological development from capital growth, rather than conflating them and condemning technology on the basis of its commercial substrate; and (2) advocating post-human scientific development and normative rationalism over appeals to 'nature' as a basis for ethico-politics. Indeed, left accelerationism takes the Promethean position that if nature is unjust then we should change nature. 
The challenge for critical sociology of education is the possibility that critique of the negative effects of the intrusion of capitalist time structures in education may not hold any potential to halt or alter the course of capitalism. The global array of interconnected, digital, algorithmic machines that control the flows of capital around the world likely stand beyond such critique and are oblivious to their socio-cultural effects. However, one could cogently argue that a relative acceleration of modernity, technology and globality, as part of broader efforts to bring about post-capitalism (or even non-capitalism), offer possibilities for working through the techonomic time of capital by selectively accelerating certain of its dimensions while actively seeking to change or ameliorate other of its negative effects. Of course, the potential success of this approach is wildly uncertain and it would require much experimentation. But acknowledging this approach as a strategic possibility could shift debates in critical studies in education into new territories.

For example, the 'opportunity trap' has been produced by a confluence of educational, technological and economic developments. However, it also reflects a sense of temporality that has long been evident in critical sociology of education: as a dialectic of progress and reproduction in which the promise of the former is continually undermined by the latter. The new capacities for data analysis described in the example above offer little potential for improving the educational opportunities of young people if they remain tethered to an 'opportunity bargain' that fails to acknowledge the transformative force of technomic time on labour and education. Indeed, these capacities risk simply accelerating the problem.

However, it may be possible to reframe the problem by beginning from the recognition of the transformative force of techonomic time and asking whether new technical capacities in education could be re-directed to transform education itself and, if so, which actors could viably pursue this aim. From this perspective, critical sociology of education could begin from the question of whether it is possible to accelerate certain tendencies in order to push schooling beyond a critical tipping point of transformation, which we could see as a form of escape from the reproductive logics of present educational forms. Singleton has argued (2014) that "[i]f a trap is to be escaped by anything other than luck ... the escapee itself must change: the thing that escapes the trap is not the thing that was caught in it" (p. 504). We see here,

... the mark of the accelerationist disposition, encompassing those schools of thought that can suborn a description of the world's perceived shortcomings, and the corresponding elaboration of how it ought to be in the shape of images of the future, to the logic of how things get done, how freedom is a possibility within this, and how its progressive maximisation can be pursued through the systematic deployment of generative constraints. (p. 507)

Here, Singleton points to the possibilities that arise from escaping a sense of accelerated temporality that is structured in terms of techno-utopia. Accelerationism could be reformatted as a part of, and adjacent to, educational practice affected by the accelerating milieu of contemporary capitalism to unlock constraint from within techonomic time. It is only by 
activating the very energies and formations of escape that one can emerge from the narrowness of established modes of critique and longstanding institutional forms of education to experiment strategically with alternatives.

The central distinction that must be kept in mind when borrowing concepts from accelerationism is that between affirming an inherently apolitical absolute deterritorialization and tactical, relative deterritorialization guided by an overarching normative strategy. As Brassier (2010, online) has argued, 'if you have no strategy, someone with a strategy will soon commandeer your tactics'. The question for critical sociology of education, insofar as it might learn from accelerationist thought experiments as part of efforts to understand the relation between learning and late capitalist time, is whether a strategic program can be forged that actively engages with technological developments such as machine learning and predictive analytics in order to put them to work in service of a strategy for accelerating cognitive development without being commandeered by the commercial forces that are rapidly colonising education.

\section{References}

Anderson, T., \& Shattuck, J. (2012). Design-Based Research: A Decade of Progress in Education Research. Educational Researcher, Vol. 41, No. 1, 16-25.

Beradi, F. (2011). After the Future. (G. Genosko \& N. Thoburn (Eds.), A. Bove, M. Cooper, E. Empson, E.G. Mecchia \& T. Terranova, Trans.). Oakland, CA: ak press.

Beradi, F. (2014). Neuro-Totalitarianism in Technomaya Google-Colonization of Experience and Neuro-plastic Alternative. Los Angeles, CA: Semiotext(e).

Blanchot, M. (2006). The proper uses of science fiction. Arena journal, No. 25/26, 375-383.

Boltanski, L. (2011). On critique: A sociology of emancipation. Polity: London.

Brassier, R. (2010). Accelerationism: Ray Brassier. Online article at: https://moskvax.wordpress.com/2010/09/30/accelerationism-ray-brassier/ Transcribed from Accelerationism Workshops at Goldsmiths

Brassier, R. (2014). Prometheanism and its critics. In R. Mackay and A. Avanessian (Eds.), \#ACCELERATE\#: The Accelerationist Reader (pp. 467-489). Falmouth: Urbanomic.

Brown, P. (2006). The Opportunity Trap. In H.Lauder, P.Brown, J.A.Dillabough, and A.H.Halsey (Eds.), Education, Globalization and Social Change (pp. 381-97), Oxford: Oxford University Press

Brown, P., Lauder, H. \& Ashton, D. (2011). The Global Auction: The Broken Promises of Education, Jobs and Incomes. Oxford: Oxford University Press. 
Brynjolffson, E. \& McAfee, A. (2014). The second machine age: Work, progress and prosperity in a time of brilliant technologies. W.W. Norton \& Company: New York.

Cole, D.R. (2014). Capitalised Education: An immanent materialist account of Kate Middleton. Winchester: Zero Books.

Cole, D.R. \& Hager, P. (2010). Learning-practice: The ghosts in the education machine. Education Inquiry, 1 (1), 21-40.

Collins, R. (2013). The end of middle-class work: No more escapes. In Wallerstein, I., Collins, R., Mann, M., Derluguian, G. \& Calhoun, C., Does capitalism have a future? New York: Oxford University Press.

Deleuze, G. (1994). Difference \& Repetition (P. Patton, Trans.). London: The Athlone Press.

Deleuze, G., \& Guattari, F. (1983). Anti-Oedipus: Capitalism \& Schizophrenia (R. Hurley, M. Seem \& H.F. Lane, Trans.). London: the Athlone Press.

Fisher, M. (2009). Capitalist Realism. London: Zero Books.

Fisher, M. (2013). A social and psychic revolution of almost inconceivable magnitude: Popular Culture's Interrupted Accelerationist Dreams. e-flux journal \#46 june 2013 (online).

Keucheyan, R. (2013). The left hemisphere: Mapping contemporary theory. Verso: London.

Kitchin, R. (2014). Big Data, new epistemologies and paradigm shifts. Big data and society, $1(1), 1-12$.

Land, N. (2011). Fanged Noumena: Collected Writings 1987-2007. Falmouth: Urbanomic.

Land, N. (2014a). Teleoplexy: Notes on Acceleration. In R. Mackay and A. Avanessian (Eds.), \#ACCELERATE\#: The Accelerationist Reader (pp. 509-520). Falmouth: Urbanomic.

Land, N. (2014b). Templexity: Disordered Loops through Shanghai Time. Urbanatomy Electronic: Kindle Edition (e)

Lindblom, J. (2012). Techno-Cultural Acceleration: A Few Initial Remarks. Earlier version of the paper appeared in: Shoppinghour \#9, Authentic Human: http://www.shoppinghourmagazine.com/?page id=18.

Luckin, R., Holmes, W., Griffiths, M. \& Forcier, L. B. (2016). Intelligence Unleashed. An argument for AI in Education. London: Pearson.

Negarestani, R. (2014). The Labour of the Inhuman. In R. Mackay and A. Avanessian (Eds.), \#ACCELERATE\#: The Accelerationist Reader (pp. 425-467). Falmouth: Urbanomic.

Nietzsche, F. (1968). The Will to Power. Vintage: New York. 
Nietzsche, F. (1877) Posthumous Fragments. Translation by Matteo Pasquinelli. http://matteopasquinelli.com/code-surplus-value/ Original quote: "Die Ausgleichung des europäischen Menschen ist der große Prozeß, der nicht zu hemmen ist: man sollte ihn noch beschleunigen. Die Nothwendigkeit für eine Kluftaufreißung, Distanz, Rangordnung ist damit gegeben: nicht, die Nothwendigkeit, jenen Prozeß zu verlangsamen".

Mackay, R. (2013). Nick Land - An Experiment in Inhumanism. Umelec magazine. Located online at: http://divus.cc/london/en/article/nick-land-ein-experiment-iminhumanismus

Mackay, R., \& Avanessain, A. (Eds.). (2014) \#ACCELERATE\# the accelerationist reader. Falmouth: Urbanomic.

Means, A. (2015). On accelerationism - decolonizing technoscience through critical pedagogy. Journal for Activism in Science \& Technology Education, 6(1). 20-27.

Mumford, L. (1934). The Myth of the Machine: Technics and Human Development. New York: Harcourt, Brace \& World.

Noys, B. (2014). Crash and Burn: Debating Accelerationism. Alexander Galloway in conversation with Benjamin Noys. Online article at: http://www.3ammagazine.com/3am/crash-and-burn-debating-accelerationism/

Pasquinelli, M. (2014). Code Surplus Value and the Augmented Intellect. Online article at: http://matteopasquinelli.com/code-surplus-value/

Richards, J. \& Stebbins, L. (2014). 2014 U.S. Education Technology Industry Market: PreK12. Washington, D.C.: Software \& Information Industry Association.

Sellar, S. (2015). Data infrastructure: a review of expanding accountability systems and large-scale assessments in education. Discourse: Studies in the Cultural Politics of Education, 36(5), 765-777.

Shaviro, S. (2013). Accelerationist Aesthetics: Necessary Inefficiency in Times of Real Subsumption. e-flux journal \#46. Online article located at: http://www.eflux.com/issues/46-june-2013/

Singleton, B. (2014). Maximum Jailbreak. In R. Mackay and A. Avanessian (Eds.), \#ACCELERATE\#: The Accelerationist Reader (pp. 489-509). Falmouth: Urbanomic.

Srnicek, N. \& Williams, A. (2015). Inventing the future: Postcapitalism and a world without work. London and New York: Verso.

Touraine, A. (2001). Beyond Neoliberalism. Cambridge: Polity Press.

Wark, M. (2015). Molecular Red: Theory for the Anthropocene. London and New York: Verso. 
Williams, A., \& Srnicek, N. (2013). \#ACCELERATE: MANIFESTO FOR AN

ACCELERATIONIST POLITICS. Online document, located at:

http://criticallegalthinking.com/2013/05/14/accelerate-manifesto-for-anaccelerationist-politics/

Wolfendale, P. (2014). So, accelerationism, what's that all about? Online document, located at: http://deontologistics.tumblr.com/post/91953882443/so-accelerationism-whatsall-that-about

Wolfendale, P. (2016). Prometheanism and rationalism. Online document, located at: https://deontologistics.wordpress.com/2016/08/20/prometheanism-and-rationalism/

Visser, S. N., Bitsko, R. H., Danielson, M. L., Gandhour, R., Blumberg, S. J., Schieve, L., Holbrook, J., Wolraich, M., Cuffe, S. (2015). Treatment of attentiondeficit/hyperactivity disorder among children with special health care needs. Journal of Pediatrics, published online April 1, 2015

\footnotetext{
i The example is drawn from a broader empirical study that investigated data production, dissemination, and use across schools and education systems in Australia, Japan, the USA, and Canada and in the education work of the OECD. The project is titled Data infrastructure, mobilities and network governance in education and is funded by an Australian Research Council Discovery Project grant (DP150102098). The Chief Investigators are Professor Bob Lingard, Associate Professor Kalervo N. Gulson, Dr Sam Sellar and Associate Professor Keita Takayama. The Partner Investigators are Professor Christopher Lubienski and Associate Professor P. Taylor Webb.
} 